\title{
Green urine in a postoperative patient
}

\author{
Hasan I A Hadi, ${ }^{1}$ Jeremy S Williamson, ${ }^{2}$ Arnab K Bhowmick ${ }^{3}$
}

1 Department of General Surgery, Glan Clwyd Hospital, Bodelwyddan, UK

${ }^{2}$ Glan Clwyd Hospital, Rhyl, UK ${ }^{3}$ Lancashire Teaching Hospital NHS Trust, Preston, Connecticut, USA

\section{Correspondence to}

Jeremy Williamson,

jswilliamson@doctors.org.uk

Accepted 25 May 2014

\section{DESCRIPTION}

An 85-year-old man underwent reversal of loop ileostomy. The integrity of the anastomosis was tested by an injection of methylene blue into the bowel lumen. Postoperatively the patient voided 'green urine' and alarmed the nursing staff and junior duty doctor (figure 1). Routine microscopic examination and culture of urine revealed no abnormality. Liver function test and full blood count was also normal. This discolouration of urine resolved spontaneously in the next few days.

Methylene blue is commonly used to test the integrity of the gastrointestinal tract following anastomosis. ${ }^{1}$ This substance is also used for diagnostic tests such as localisation of parathyroid adenoma during surgery and identification of fistula tracts, as a therapeutic agent for the treatment of methemoglobinaemia or refractory hypotension and as a mild antimicrobial agent. This dye is converted into leucomethylene blue by gastrointestinal bacterial flora and mostly excreted in the urine.

The yellow colour of urine is attributed to the compound urochrome. When it combines with methylene blue, a harmless compound is formed which creates a green or greenish blue colour. ${ }^{2}$ The intensity of the green colour in urine is the dose related. Some medications such as propofol, cimetidine, promethazine, metoclopramide, amitryptiline and indomethacin can also cause green urine. Careful history, physical examination and awareness of this self-limiting condition are important to avoid anxiety and unnecessary investigations on such urine samples.

\section{Learning points}

- Methylene blue is commonly used for both diagnostic and therapeutic purposes.

- As it is mostly excreted by the kidney, it can cause discolouration to the urine.

- Patients and staff should be warned or be aware of this potential cause of self-limiting urine discolouration to avoid unnecessary anxiety and investigation.

Contributors HIH and JW helped in literature search and wrote the manuscript. $A B$ identified the case and treated the patient. All reviewed the manuscript and approved.

\section{Competing interests None.}

Patient consent Obtained.

Provenance and peer review Not commissioned; externally pee reviewed.

\section{REFERENCES}

1 Prosst RL, Reinecke F, Geginat G. Methylene blue in the evaluation of gastrointestinal tract integrity: potential limitations. Eur Surg Res 2005;37:246-9.

2 Acock R, Kass D. Abnormal urine colour. South Med 2012;105:43-7.

\section{To cite: Hadi HIA}

Williamson JS,

Bhowmick AK. BMJ Case Rep Published online:

[please include Day Month

Year] doi:10.1136/bcr-2014204986

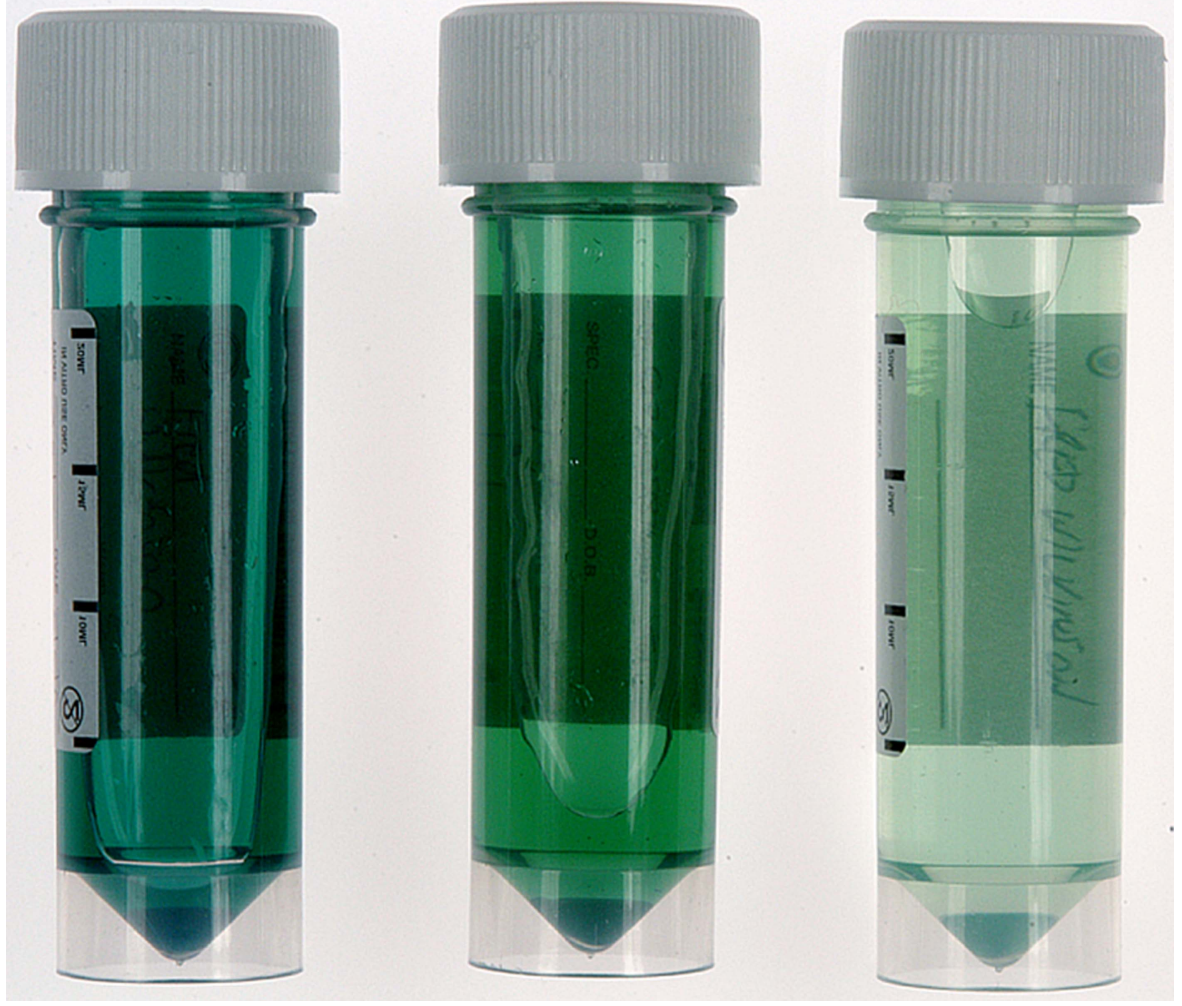

Figure 1 Sample of green urine with progressive colour change. 
Copyright 2014 BMJ Publishing Group. All rights reserved. For permission to reuse any of this content visit http://group.bmj.com/group/rights-licensing/permissions.

BMJ Case Report Fellows may re-use this article for personal use and teaching without any further permission.

Become a Fellow of BMJ Case Reports today and you can:

- Submit as many cases as you like

- Enjoy fast sympathetic peer review and rapid publication of accepted articles

- Access all the published articles

- Re-use any of the published material for personal use and teaching without further permission

For information on Institutional Fellowships contact consortiasales@bmjgroup.com

Visit casereports.bmj.com for more articles like this and to become a Fellow 